\title{
The study of glycopeptide syntheses: exploring concise $O$-linked sialylglycopeptide synthesis and glycopeptide coupling reaction
}

\author{
糖ペプチドの合成研究 : \\ 簡便な $\mathbf{O}$ 型シアリル糖ペプチドの合成と糖ペプチド連結法の探索
}

\author{
Okamoto, Ryo; and Kajihara, Yasuhiro* \\ International Graduate School of Arts and Sciences, Yokohama City University, \\ 22-2 Seto, Kanazaw-ku, Yokohama 236-0027, Japan \\ *Corresponding author: kajihara@yokohama-cu.ac.jp
}

(Received on August 6, 2008, accepted on August 6, 2008)

Key Words: Sialylation, Sialyl- $T_{N}, M U C 4$, sialylglycopeptide

\begin{abstract}
For the preparation of both $N$-linked and $O$-linked sialylglycopeptides and their glycoprotein form, the critical points in these syntheses are the preparation of an appropriate amount of sialyloligosaccharyl-amino acid and isolation of the sialylglycopeptides. In particular, it have been difficult to isolate $O$-linked sialylglycopeptides in which the sialyl linkage is labile to acid treatment and the $\mathrm{N}$-acetyl-galactosaminyl linkage is labile to base-treatment. For the preparation of target glycoproteins by the use of such sialylglycopeptide thus obtained, an efficient coupling method should be essential. In this review, we introduce our new sialyl donors for the synthesis of sialyl- $\mathrm{T}_{\mathrm{N}}$ epitope and $O$-linked sialyl- $\mathrm{T}_{\mathrm{N}}$-glycopeptides, and a new concept for a glycopeptide coupling reaction in the synthesis of glycoproteins.
\end{abstract}

\section{A. Introduction}

Polypeptide chains are modified by co- or posttranslational modifications. Of these, glycosylation is the major modification and $50 \%$ of all human proteins are thought to be glycosylated (1). Oligosaccharides on glycoprotein are basically divided into two groups, $O$ linked and $N$-linked types (2). In the case of the $O$-linked type, a small oligosaccharide attaches to the alcohol of serine or threonine by an $N$-acetyl- $\beta$-D-galactosaminyl linkage. On the other hand, the $N$-linked type is a large branched oligosaccharide, which is further divided into three types: complex, hybrid, and high-mannose types. All $N$-linked oligosaccharides are incorporated on the asparagine side chain, where asparagine is located in the Asn-X-Thr/Ser sequence (X: any amino acid except for proline). However, since the oligosaccharides on proteins exhibit diverse structures, elucidation of oligosaccharide
要 約

$\mathrm{N}$ 型， $\mathrm{O}$ 型シアリル糖ペプチド抢よびその糖タンパク質 を調製するために, 最も大事なことは, 必要量のシアリル糖 鎖一アミノ酸とそれを用いたシアリル糖鎖ペプチドの合成を いかに行うかである. 特に, 酸に弱い, シアリル結合打よび 塩基に弱い $\mathrm{N}$-アセチルガラクトサミン結合をもつ $\mathrm{O}$ 型シア リル糖ペプチドを単離することは注意が必要である。そし て, それらシアリル糖ペプチドを用いて, 標的糖タンパク質 を調製する場合，ペプチドや糖ペプチドを連結する簡便な方 法が必要である。この総説では, シアリル- $\mathrm{T}_{\mathrm{N}}$ エピトープを 合成するための, 新しいシアリル供与体抢よび, $\mathrm{O}$ 型シアリ ルー $\mathrm{T}_{\mathrm{N}}$ 糖ペプチドの合成, さらには, 糖タンパク質を合成す るための, 糖ペプチド連結法について最近の我々の成果を紹 介する。

\section{A. はじめに}

ポリペプチド鎖は, 翻訳中あるいは翻訳後修飾を受け る。これらの中で, 糖鎖化は, もっとも主要な修飾で, ヒト タンパク質のうち約 $50 \%$ が糖鎖化されている可能性がある (1)。糖鎖は，大きく 2 つのグループに分けることができる。 $\mathrm{O}$ 型, 抢よび $\mathrm{N}$ 型である。 $\mathrm{O}$ 型については, 少数の糖残基が 連結した形で, タンパク質中のセリンあるいはトレオニンに N-アセチルガラクトサミンを介して結合している(2)。一方, $\mathrm{N}$ 型は, 大型で分岐構造を形成し, さらに3つのタイプ, 複 合型, 混成型, 高マンース型に分けられる。全ての N 型糖鎖 は, Asn-X-Thr/Ser(X はプロリン以外)のアスパラギン残基の 側鎖の窒素原子に結合している。しかし, 糖鎖は, 多様な構 造をしているのでどのような構造の糖鎖が機能しているのか 解明するのは困難である。従って, 単一構造の糖鎖をもつ糖 タンパク質を調製することが必要である。近年では, 糖鎖機 

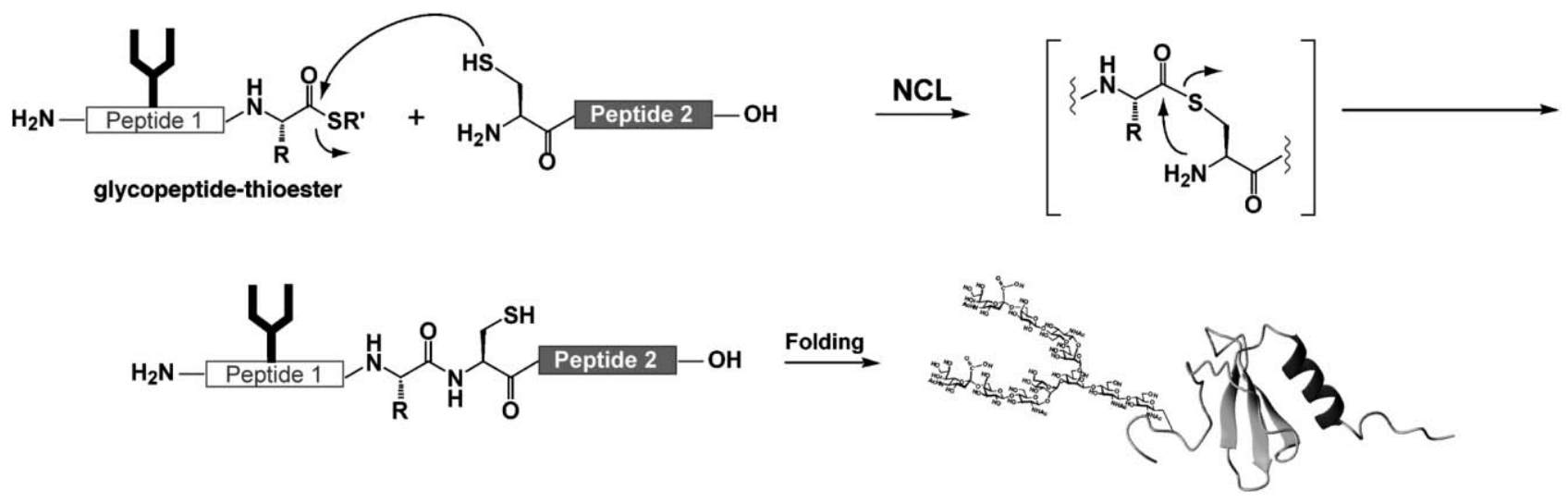

Fig. 1. Native chemical ligation and glycoprotein synthesis.

function on proteins has been difficult. Therefore, glycoproteins having homogeneous oligosaccharides need to be prepared. Recently cell expression systems for the study oligosaccharide function have advanced, but as yet it cannot regulate the oligosaccharide patterns precisely. Under these situations, chemical syntheses have been expected which would allow the preparation of homogeneous glycoproteins having complex type and $O$-linked oligosaccharides. In terms of the synthesis of glycoproteins having $O$-linked sugars, the Bertozzi (3) and Nakahara groups (4) have independently succeeded. For the synthesis of glycoproteins having complex type oligosaccharides, we demonstrated the synthesis of monocyte chemotactic protein-3 having a complex type disialyloligosaccharide (5). There are still problems in the synthesis of a number of glycoproteins, however, which remain to be solved.

For preparation of the target glyco-polypeptide chain, peptide and glycopeptide segments should be coupled. The Nakahara and Hojo group used a peptidethioester activation strategy using $\mathrm{AgCl}$ (6), while Bertozzi (3) and our groups (5) employed the native chemical ligation (NCL) method developed by Kent and Dawson (Fig. 1) (7). This NCL method relies on the thiol exchange reaction between a peptide having a $\alpha$-thioester at the $C$-terminal and another peptide having a cysteine residue at the $N$ terminal, and subsequent intramolecular acyl transfer to afford a native amide bond. This method can be performed in the buffer solution without any activated organic reagents except for guanidine-hydrogenchloride and alkyl-thiol. As shown in Figure 1, this NCL absolutely requires a cysteine residue at the $N$-terminal of the peptide. However, some target glycoproteins don't have cysteine at the appropriate position for the peptide segment coupling reaction. Therefore, in order to couple glycopeptides segments at any position, a new ligation method is also essen-
能を解明するための, 細胞を用いた発現法が発展している が，糖鎖構造を精密に制御することはできない。このような 状況下では, 単一構造の複合型, あるいは $\mathrm{O}$ 型糖鎖をもつ糖 タンパク質の化学合成が期待されている。 $\mathrm{O}$ 型の単糖をもつ 糖タンパク質の合成では, $\operatorname{Bertozzi}(3)$ 抢よび中原 (4)グループ がそれぞれ成功している。複合型シアリル糖鎖をもつ糖タン パク質の合成としては, 我々が, monocyte chemotactic protein-3の合成を抢こなっている(5)。しかしながら，今後多く の糖タンパク質を合成していくには, 解決しなくてはならな い問題が残っている。

標的糖タンパク質の糖ペプチド鎖を調製するには，ペプ チドや糖ペプチドセグメントを連結する必要がある。中原, 北條グループ(6)は，ペプチドチオエステルをもちい，それを 塩化銀で活性化してペプチド鎖を連結している。一方, Bertozzi (3), 我々は (5), Kent, Dawsonらが見出した native chemical ligation（NCL）を利用している(7)。この反応では, $\mathrm{C}$ 末端にチオエステル基をもつペプチドとシステイン残基を $\mathrm{N}$ 末端にもつペプチド間のチオール交換反応が抢こり，そし て分子内アシル転移を起こすことで, 天然型のアミド結合を 与える(図 1)。この反応は, タンパク質変性剤であるグアニジ ン存在下, 緩衝溶液中で活性化剂を用いなくても起こる。図 1 に示したように, NCL は, システイン残基を必要とする。し かし, 標的糖タンパク質全長を構築する際, ペプチドを連結 していくために必要なシステイン残基を適切な位置にもって いないタンパク質がある。したがって, システイン残基以外 の場所でも糖ペプチド, ペプチドを連結できる方法が必要で ある。 
tial.

For preparation of $O$-linked sialylglycopeptides and their glycoprotein form, the critical points in these synthetic methods are the preparation of an appropriate amount of sialyloligosaccharyl-amino acid and isolation of the $O$-linked type sialylglycopeptide in which the sialyl linkage is labile for acid treatment and the $\mathrm{N}$-acetyl-galactosaminyl linkage is labile for base-treatment. Hence, an annoying problem is the stereoselective construction of the naturally occurring $\alpha$-sialyl linkage. Because $O$-linked sialylglycopetide and its protein form have been expected for cancer vaccines (8) and cancer immunotherapy using humanized IgG, efficient $O$-linked sialylglycopeptides have been anticipated.

Under these situations, we have undertaken an effort to solve these problems. In this review, we would like to introduce an interesting finding regarding a new sialyl donor for the synthesis of sialyl- $\mathrm{T}_{\mathrm{N}}$ epitopes and $O$-linked sialyl $\mathrm{T}_{\mathrm{N}}$-glycopeptides (9), and a new concept for glycopeptide coupling reactions for the synthesis of glycoproteins (10).

\section{B. Sialylation}

A variety of sialyl donors for sialylation have been reported (11) and these are divided into two groups. Some donors act by the solvent effect using acetonitrile for the regulation of stereoselectivity (11-13), while the other group utilizes the neighboring group effect $(11,14)$. In addition, modification of the acetamide group at the 5 position was found to elevate $\alpha$-selectivity $(11,15-22)$. Because all of the sialyl donors reported have an ester group at the 1-position (Fig. 2, 4) (23), we have an interest in the ability of an amide group at the 1-position instead of an ester group (Fig. 2, 1-3).

Therefore we started to investigate reactivity and stereoselectivity of amide donors to serve as a new sialyl donor. We selected three amide functional groups, amide $\left(\mathrm{CONH}_{2}\right)$, monomethyl amide $\left(\mathrm{CONHCH}_{3}\right)$, and dimethyl amide $\left(\mathrm{CON}\left(\mathrm{CH}_{3}\right)_{2}\right)$ groups 1-3 as shown in Fig. 2.

For the synthesis of amide and monomethylamide donors, we used methyl 5-acetamido-3,5-dideoxy- $\beta$-Dglycero-D-galacto-2-nonulopyranosonate (Neu5Ac-1methyl ester, 5 (24)) as the starting substrate. For the syn-
$\mathrm{O}$ 型のシアリル糖鎖ペプチド抢よびその糖タンパク質を 合成することについては，合成に必要な，シアリル糖鎖一アミ ノ酸の調製抢よび酸加水分解されやすいシアリル結合, 塩基 に弱いガラクトサミン結合を有する $\mathrm{O}$ 型シアリル糖鎖ペプチ ドをいかに単離するかが鍵となる。また，さらに問題となる のは，シアリル糖鎖調製のための立体選択的なシアリル化で ある。O 型シアリル糖鎖は, 癌ワクチン $(8)$ や, ヒト IgG を用 いた抗体治療のための抗原としても期待されているので，上 り簡便な $\mathrm{O}$ 型シアリル糖鎖ペプチドの合成法が望まれてい る。このような状況下で我々は，これら問題点を解決する検 討を行ってきた。この総説では, シアリル $\mathrm{T}_{\mathrm{N}}$ 抗原, およびシ アリル $\mathrm{T}_{\mathrm{N}}$ を有するペプチドを合成するのに有用な興味深いシ アリル化反応を見出したこと(9), また糖タンパク質を合成す るための新しい糖ぺプチドを連結法(10) も開発したことを紹 介する。

\section{B. シアリル化反応}

シアリル化のための有用なシアリル供与体が多数開発さ れていきたが(11)，それらは，2つのグループに分けることが できる。アセトニトリルの溶媒効果を利用したものと（1113)，隣接基効果を利用したものである $(11,14)$ 。さらに最近 は, シアル酸の 5 位を修飾すると $\alpha$ 選択性が向上することが 報告されている(11,15-22)。しかし，全てのシアリル供与体 の 1 位はエステル基であり（図 2,4)(23), 我々は, このエス テルをアミド基に置換した効果に興味をもった（図 2, 1-3）。 そこで，アミドを有する新しいシアリルドナーの反応性, 立 体選択性を調べる研究を開始した。我々は, シアル酸の 1 位 にアミド，モノメチルアミド，そしてジメチルアミド基を有 する化合物を選び合成した（図 2, 1-3）。

アミド抢よびモノメチルアミド供与体の合成は, methyl 5 -acetamido-3,5-dideoxy- $\beta$-D-glycero-D-galacto-2-nonulopyranosonate (Neu5Ac-1-methyl ester, 5) (24) を出発原料にした。 ジメチルアミド供与体は，へキサアセチルシアル酸 10 を出発 原料にした(25)。これらアミド誘導体の合成は, Scheme 1 に 示したように，一般的な反応を用いて合成した。新しいシア

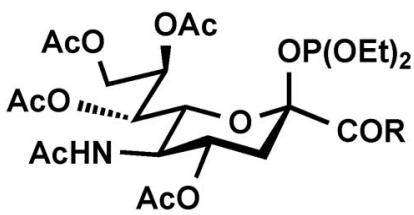

$$
\begin{aligned}
& \text { 1: } \mathrm{R}=\mathrm{NH}_{2} \\
& \text { 2: } \mathrm{R}=\mathrm{NHCH}_{3} \\
& \text { 3: } \mathrm{R}=\mathrm{N}\left(\mathrm{CH}_{3}\right)_{2} \\
& \text { 4: } \mathrm{R}=\mathrm{OCH}_{3}
\end{aligned}
$$

Fig. 2. Novel sialyl donors and conventional donors. 

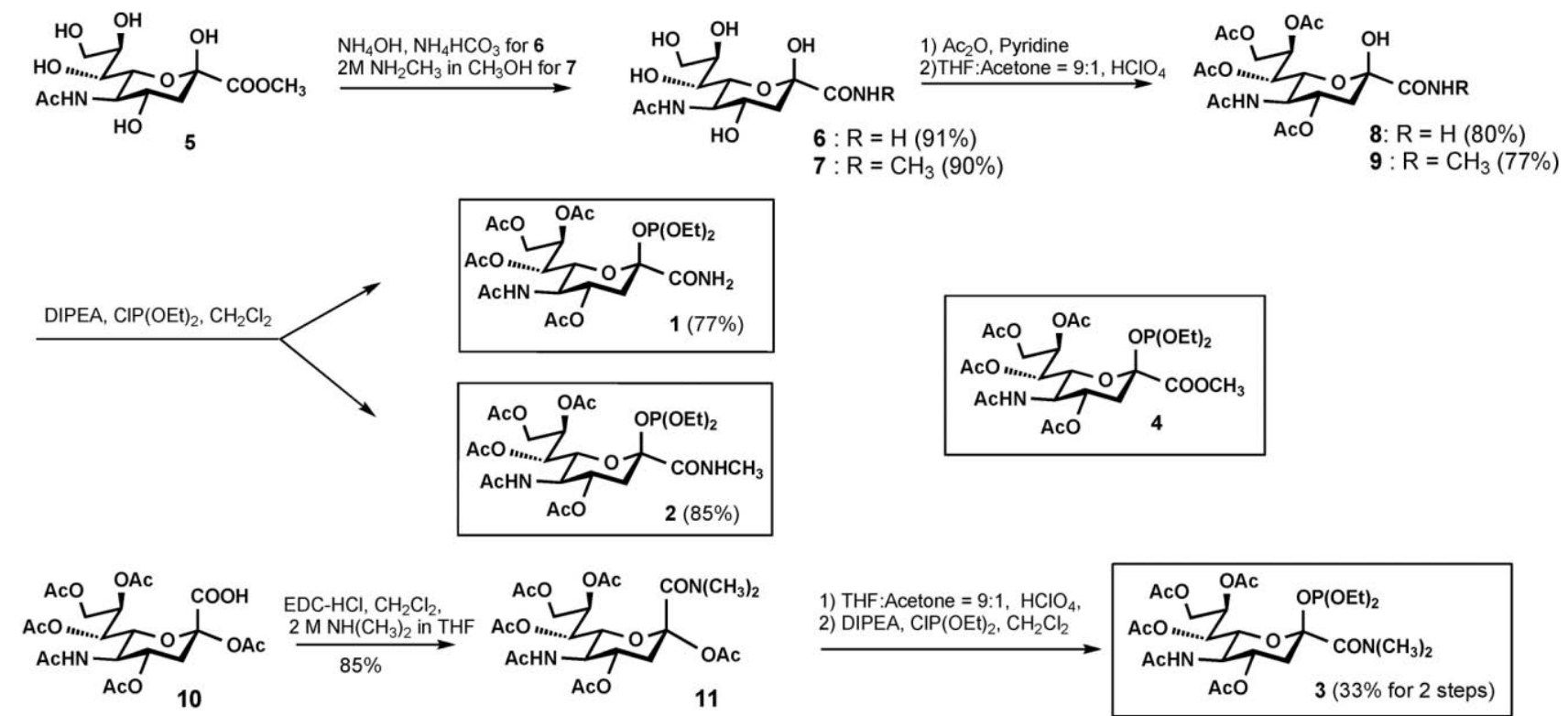

Scheme 1. Synthesis of amide donors 1-3.

thesis of the dimethyl amide donor, we used hexaacetylNeuAc derivative $\mathbf{1 0}$ as the starting substrate (25). These amide donors 1-3 were synthesized under conventional conditions, as shown in Scheme 1.

The new sialyl donors 1-3 were examined for the sialylation reaction toward the 6-hydroxyl group of acceptors (a)-(c). In terms of sialylation of glucoside acceptor (a) with amide donor 1, the reaction afforded sialoside $\mathbf{1 2}$ in $84 \%$ yield $(\alpha: \beta=7: 1$, entry 1). Sialylation using monomethyl amide donor 2 with acceptor (a), afforded sialoside $\mathbf{1 5}$ in $90 \%$ yield ( $\alpha: \beta=10: 1$, entry 4$)$. Using the galactosyl type acceptors (b) and (c), this reactions also afforded the desired Neu5Ac- $\alpha-(2,6)-$ Gal and Neu5Ac- $\alpha$ $(2,6)$-GalNAc linkages in good yield, respectively $(\alpha: \beta=$ $4.5: 1$, entry $2 ; \alpha: \beta=4: 1$, entry 3). Furthermore, the monomethyl amide donor 2 exhibited better $\alpha$-selectivity and higher yield (yield $=91 \%, \alpha: \beta=5: 1$, entry $5 ; \alpha: \beta=$ 5.4:1, entry 6). Meanwhile, dimethylamide donor 3 toward acceptor (b) and (c) afforded an unexpected result. These reactions exhibited $\beta$-selectivity rather than $\alpha$-selectivity ( $\alpha: \beta=1: 6$, entry 7 , and $\alpha: \beta=1: 9$, entry 8 ). In order to evaluate the function of amide group during sialylation, we also examined the normal sialylation reaction using a methyl ester donor 4 in $\mathrm{CH}_{2} \mathrm{Cl}_{2}$. The stereoselectivity ranged from 4:1 $(\alpha: \beta)$ to $1: 1$ (entry 9-11).

Based on these results, we hypothesized that activation of the amide donor afforded a three membered cyclic intermediate generated by the interaction of the amidegroup with the $\mathrm{C}(2)$ position to stabilize the oxocarbenium ion intermediate (Fig. 3).
リル供与体 1-3 を用いて, 受容体(a)-(c) の 6 位水酸基に対し てシアリル化を塩化メチレン溶媒中で検討した。グルコース 受容体を用いたアミド供与体 1 のシアリル化については, シ アリル糖鎖 12 を $84 \%$ の収率で与えた $(\alpha: \beta=7: 1$, entry 1$)$ 。 モノメチルアミド供与体 $\mathbf{2}$ では，シアリル糖鎖 $\mathbf{1 5}$ を $90 \%$ の 収率で与えた $(\alpha: \beta=10: 1$, entry 4)。ガラクトシルタイプの 受容体 (b) 抢よび (c) を用いた場合, Neu5Ac- $\alpha-(2,6)-\mathrm{Gal}(\alpha$ : $\beta=4.5: 1$, entry 2) 抢よび Neu5Ac- $\alpha-(2,6)-\operatorname{GalNAc}(\alpha: \beta=$ $4: 1$, entry 3) を効率よく与えた。更に, モノメチルアミド供 与体 2 を用いると, さらに高い $\alpha$ 選択性と收率向上が見られ た $($ yield $=91 \%, \alpha: \beta=5: 1$, entry $5 ; \alpha: \beta=5.4: 1$, entry 6)。しかし，ジメチルアミド供与体 3 を用いるとその選択性 は $\beta$ 型へと変化した $(\alpha: \beta=1: 6$, entry 7, and $\alpha: \beta=1: 9$, entry 8 )。

アミド基の効果を調べるために，我々は，メチルエステ ルを有する一般的なシアリル供与体 4 を塩化メチレン中で反 応させた。その結果, 立体選択性は, $4: 1(\alpha: \beta)$ から $1: 1$ (entry 9-11)であった。

これら結果をもとに, 我々は, 活性化したアミド供与体 は, 生成する 2 位のオキソカルベニウムイオンとアミドが相 互作用した 3 員環様の中間体を生成していると考察した（図 3)。この過程では, 2 つの中間体 (a)あるいは (b)が存在する 可能性がある。実験は, $\alpha$ 選択性を優位に示すことから, 中 間体は (b) が優先していると推定している。また, ジメチルア 
Table 1. Sialylation using amide donors 1-3 and conventional methyl ester donor 4

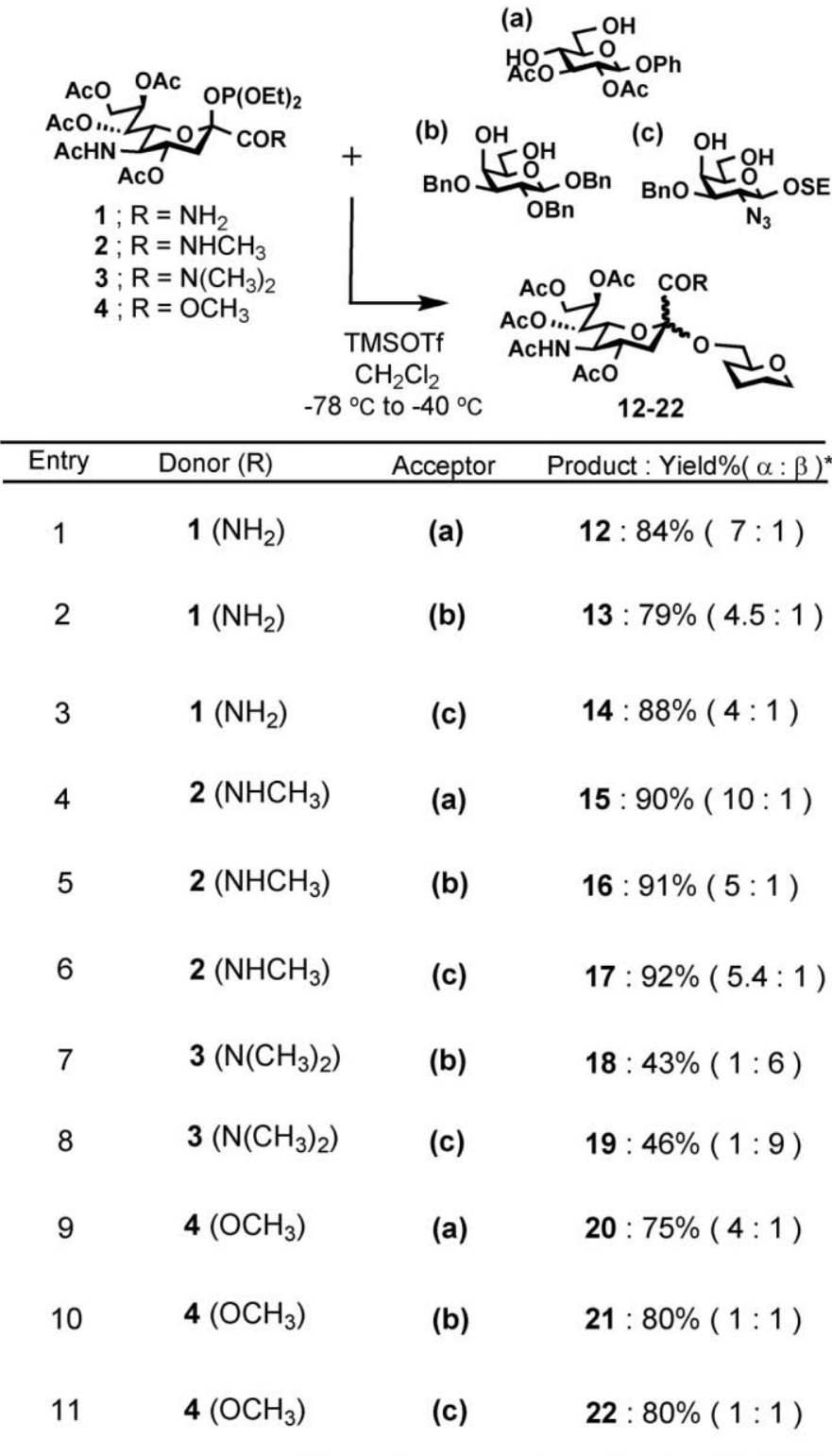

*The ratios were determined by ${ }^{1} \mathrm{H}$ NMR

During this process, we hypothesize that there are two possible intermediates, (a) or (b). Because experiments exhibited $\alpha$-selectivity rather than $\beta$-selectivity, the intermediate (b) may be dominant during this sialylation. In the case of a dimethyl amide donor, we hypothesized that these three membered intermediate could not be formed due to steric hinderance of the dimethyl group.

We also found an interesting stereoselectivity dependent on the reaction temperature, as shown in Table 2 .

All experiments exhibited better $\alpha$-selectivity at $-87^{\circ} \mathrm{C}$. According to these results, we hypothesize that the formation of intramolecular cyclization having a $\beta$ -

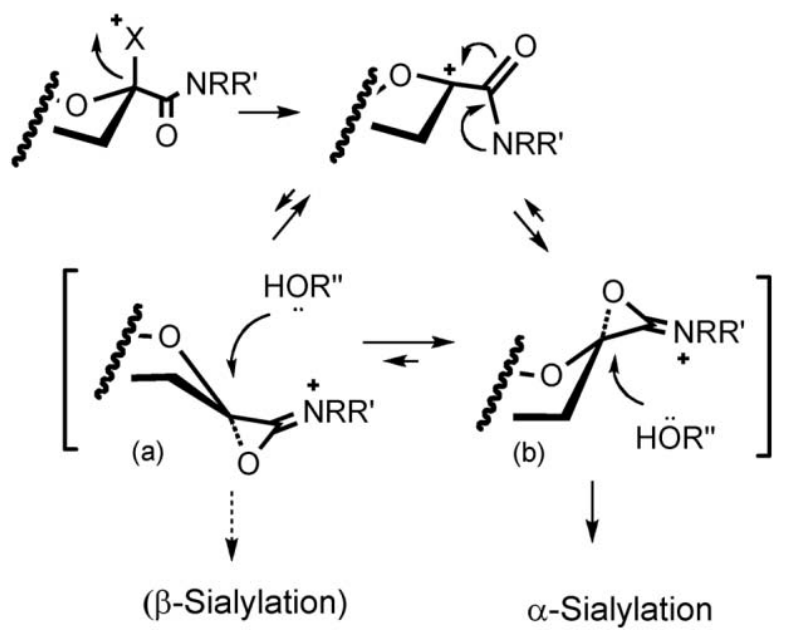

Fig. 3. Presumable reaction mechanism of the new sialylation.

ミド供与体では，この中間体形成がジメチル基の立体障害に より効率よく起こらないために， $\beta$ 選択性を示したのではな いかと考えている。

また, 我々は, この興味深い選択性は, 反応温度に依存 して変化することを見つけた。その結果を表 2 に示した。全 ての反応に抢いて， $-87^{\circ} \mathrm{C}$ でより高い $\alpha$ 選択性を示した。こ の結果に従い, 我々は, 図 3 に示した中間体 (b)がグリコシ レーションより先に起こっているのではないかと推定した。 すなわち，低温で反応させると溶媒を排除しながら受容体が シアリル供与体へ接近し反応する分子間反応速度が低下する 

Table 2. Temperature dependence of sialylation reaction using Neu5Ac-1-
monomethylamide 2

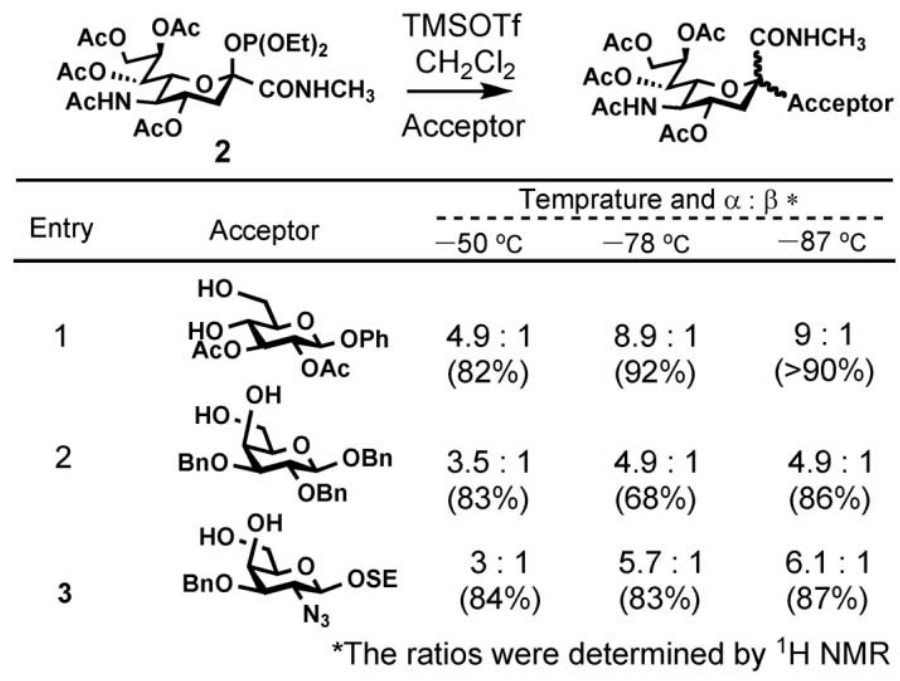

Table 3. Deamidation of 1-amide-sialosides

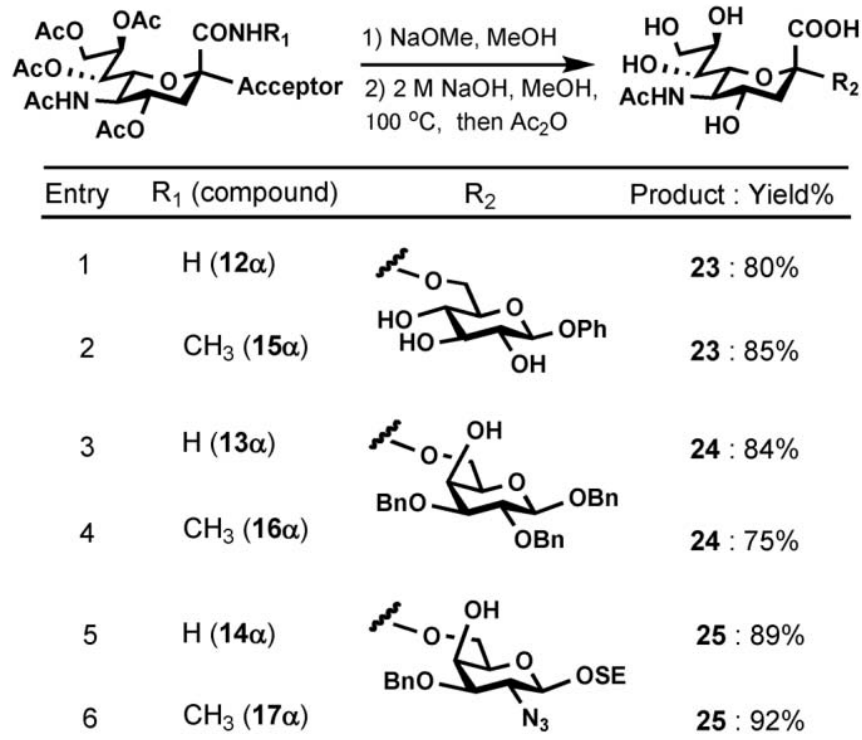

configuration, as shown in Fig. 3 (b), may be faster than that of glycosylation. This is because the lower temperature condition decreases the accessibility of acceptor to the sialyl donor through solvent due to an intermolecular reaction. Therefore, alcohol might attack the $\mathrm{C}(2)$ carbon from the $\alpha$-side preferably after the formation of the thermodynamically stable intermediate (b).

Because we found an interesting sialylation reaction by amide donors, we examined deamidation reaction at the 1 position. Hydrolysis by the use of $2 \mathrm{M} \mathrm{NaOH}$ solution at $100^{\circ} \mathrm{C}(26)$ followed by acetamidation with $\mathrm{Ac}_{2} \mathrm{O}$ at the 5 position afforded the desired sialoside in good yield. The results of deamidation are shown in Table 3.
ため, 中間体 (b)を形成する分子内反応の方が早いと考えら れ，その結果，受容体のアルコールは中間体形成後， $\alpha$ 方向 から中間体(b)に攻撃し， $\alpha$ 体を与えるのではないかと考えて いる。

我々は，アミド供与体を用いた興味深いシアリル化を見 出したので，次にアミド基のデアミド化を検討した。2M $\mathrm{NaOH} 100^{\circ} \mathrm{C}$ で処理後 (26)，5位のアセトアミド化を行い，目 的とするシアリル糖鎖を得ることができた。この結果は，表 3 に示した。全てのアミド供与体を用いたシアリル化反応の選 択性は，このようにデアミド化を行ってNMR を用いて決定 した。 


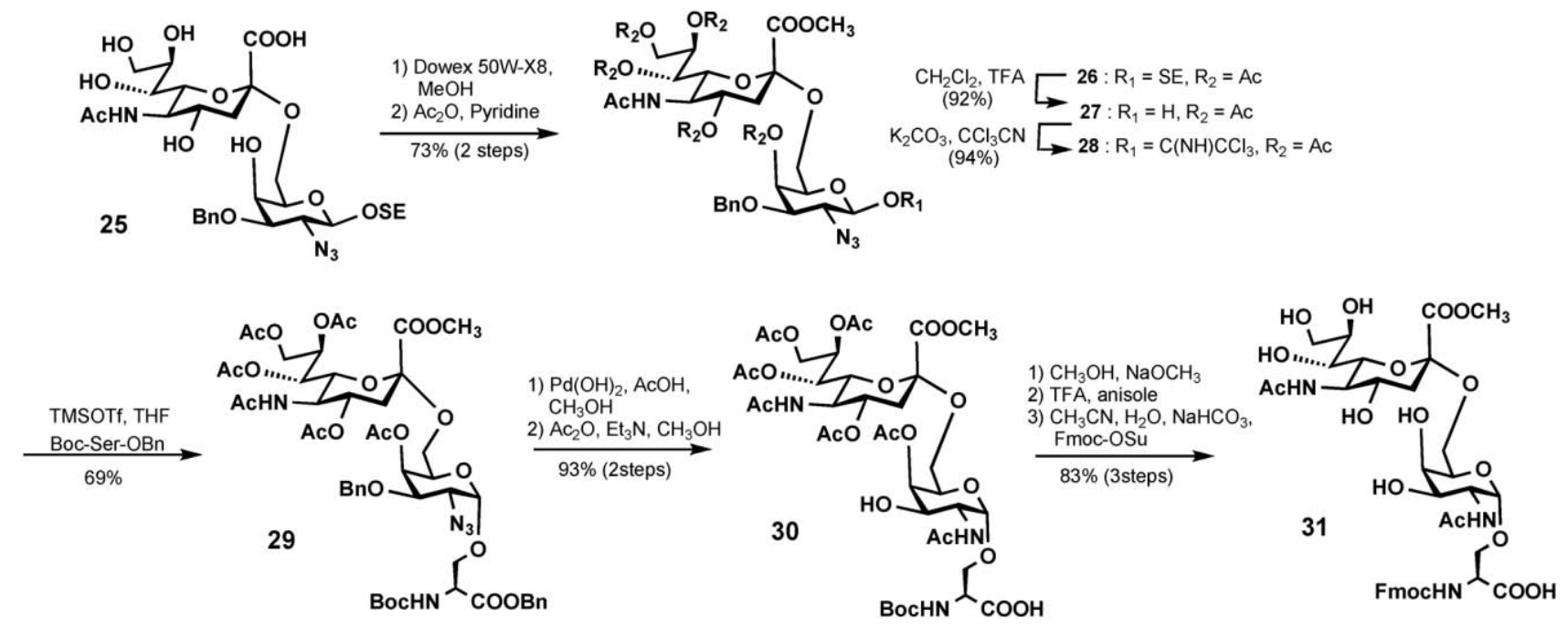

Scheme 2. Synthesis of sialyl- $T_{\mathrm{N}}$ derivative 31

\section{Synthesis of sialyl- $T_{N}$ serine derivative and sialyl- glycopeptide}

Because the sialylation afforded a suitable amount of sialyldisaccharide, we examined synthesis of naturally occurring $O$-linked sialylglycopeptides. We selected MUC4 glycopeptide having the sialyl- $\mathrm{T}_{\mathrm{N}}$ epitope (sialyl$\mathrm{T}_{\mathrm{N}}$-MUC4 peptide), which is found as an antigen of tumor-associated glycoproteins and is potentially an immune response target (27-29). For the synthesis of this $O$-linked sialylglycopeptide, we examined the synthesis of Fmoc-Ser(sialyl- $\mathrm{T}_{\mathrm{N}}$ )-OH by using sialydisaccharide $\mathbf{2 5}$ (Scheme 2) (30).

After esterification and acetylation of $\mathbf{2 5}$, the trimethylsilylethyl (SE) group at the 1-position of Gal-2$\mathrm{N}_{3} 26$ was removed by TFA. Disaccharide 27 was converted into imidate 28 in order to examine glycosylation with the Boc-N-Serine derivative. This glycosylation afforded sialyl- $T_{N}$ derivative 29 in moderate yield (31). After deprotection steps, we obtained Fmoc-Ser(sialyl- $\left.\mathrm{T}_{\mathrm{N}}\right)-\mathrm{OH}$ conjugate 31, in which the hydroxyl group is free.

For the synthesis of the sialyl- $\mathrm{T}_{\mathrm{N}}-\mathrm{MUC} 4$ glycopeptide by solid phase peptide synthesis, we used 31, because we have already demonstrated the synthesis of $N$-linked glycopeptides by the use of an Fmoc-Asn-complex type oligosaccharide having a free sugar hydroxyl group (32). We thought that using this oligosaccharyl-amino acid $\mathbf{3 1}$ with the free hydroxyl group would avoid the deprotection step of the acetyl group under basic condition, which usually causes $\beta$-elimination of amino acids. In addition, we also found that the esterified sialyl-linkage exhibited resistance in the 95\% TFA condition, which is the general condition for the cleavage from the resin (scheme 3). Therefore we examined the synthesis of glycopeptides hav-
C. シアリルーT $\mathrm{N}_{\mathrm{N}}$ セリン誘導体とシアリルペプチドの合成

我々のシアリル化は，適量のシアリル糖鎖を与えること ができるので, 天然型に存在する $\mathrm{O}$ 型シアリルペプチドの合 成を検討した。我々は, 免疫応答が期待される腫瘍抗原, シ アリルー $\mathrm{T}_{\mathrm{N}}$ エピトープを有する MUC4 糖ペプチドを選んだ (27-29)。このＯ型シアリルペプチドの合成については，合成 したシアリル糖鎖 25 を用いて, Fmoc-Ser ( sialyl-T $\left.\mathrm{N}_{\mathrm{N}}\right)-\mathrm{OH}$ を合 成することから検討した（Scheme 2)（30）。基質 25 のエステ ル化とアセチル化後, Gal-2-N 26 の 1 位のトリメチルシリル 基を $\mathrm{BF}_{3}-\mathrm{Et}_{2} \mathrm{O}$ により脱保護した。そして 27 を Boc-N-Serine をグルコシル化するためイミダート体 $\mathbf{2 8}$ へと変換した。28 と Boc-N-Serine の側鎖水酸基へのグリコシル化の後 (31), 脱保 護, 保護基の導入を経て, 水酸基のみ遊離の Fmoc-Ser ( sialyl$\mathrm{T}_{\mathrm{N}}$ ) -OH 31 を得た。

シアリル- $\mathrm{T}_{\mathrm{N}}-\mathrm{MUC4}$ 糖ペプチドの固相合成は, 既に遊離 水酸基をもつ複合型糖鎖が糖ペプチドの合成に利用できたよ うに(32)，ここでも水酸基遊離の Fmoc-Ser ( sialyl- $\mathrm{T}_{\mathrm{N}}$ )-OH 31 を用いる。この水酸基遊離の Fmoc-Ser ( sialyl- $\mathrm{T}_{\mathrm{N}}$ )-OH 31 は, 水酸基の保護基として利用されるアセチル基の塩基処理によ る脱保護操作を必要としないことから， $\beta$ 脱離などの副反応 をさけることができると考えた。また, 我々は, エステル化 したシアロシドは, 固相合成の最終工程で行う 95\% TFA 処理 に耐性を示すことを事前に確認した。そこで，シアリルー $\mathrm{T}_{\mathrm{N}}$ 糖ペプチドの合成を検討した (Scheme 3)。 


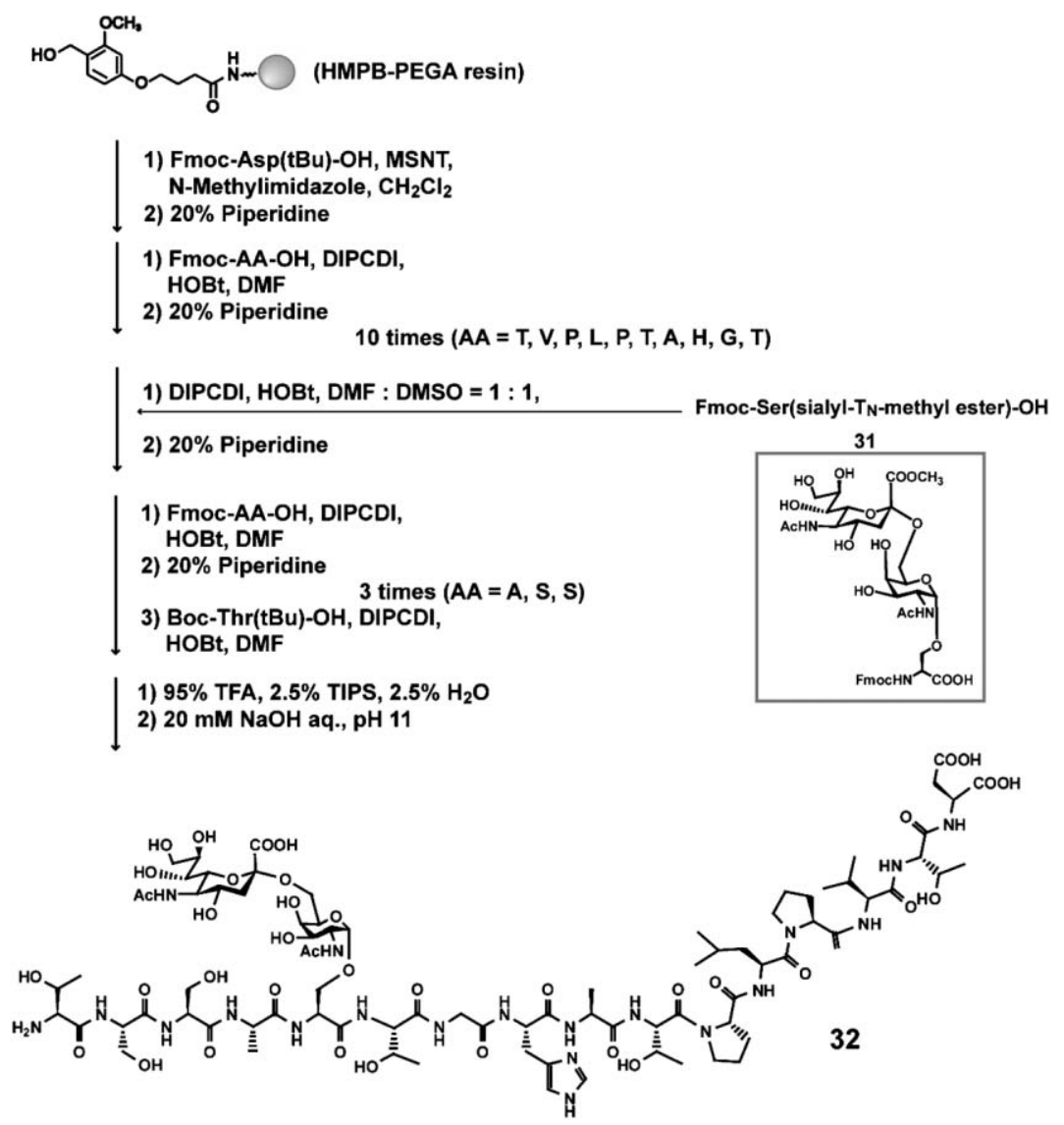

Scheme 3. Solid phase synthesis of sialyl-T $\mathrm{N}_{\mathrm{N}}-\mathrm{MUC4}$ glycopeptide 32

ing the sialyl- $\mathrm{T}_{\mathrm{N}}$ conjugate.

We used poly(ethyleneglycol)-poly(dimethylacrylamide) copolymer (PEGA) resin, which contains the acidlabile linker 4-(4-hydroxymethyl-3-methoxy-phenoxy)butyric acid (HMPB). This method was used for the synthesis of several glycopeptides having complex type sialyloligosaccharides. The synthesis was pursued as in the previous reaction condition. The first residue, aspartic acid, was introduced by 1-(mesitylenesulfonyl)-3-nitro1,2,4-triazole (MSNT) and $N$-methylinidazole. The second to eleventh residues were coupled by diisopropylcarbodiimide (DIPCDI) and hydroxybenzotriazole (HOBt) in DMF. In terms of incorporation of 31, a conventional condition using DIPCDI and HOBt was used. The following amino acid residues were incorporated by the same reagents, but $40 \mathrm{mM}$ concentration of amino acids was essential to avoid esterification of the sugarhydroxyl group on sialyl- $\mathrm{T}_{\mathrm{N}}(32)$. After construction of the glycopeptide, the glycopeptide was released from the resin by treatment with TFA $/ \mathrm{H}_{2} \mathrm{O}(95: 5)$ for $2 \mathrm{~h}$. This condition afforded the desired sialylglycopeptide. Subsequent brief saponification of the methyl ester was performed by 200
この固相合成では, poly（ ethyleneglycol）-poly (dimethylacrylamide) copolymer (PEGA) 樹脂に酸加水分解処 理に敏感な 4- (4-hydroxymethyl-3-methoxy-phenoxy) -butyric acid（HMPB）リンカーを組み合わせて利用した。この方法で 幾つかの複合型糖鎖をもつ糖ペプチドを合成して抢り，本合 成でもこの条件を用いた。最初のアミノ酸はMSNTを用いて 導入し，そして 2 つ目以降のアミノ酸は, カルボジイミドで ある DIPCDI および HOBt をDMF 中で用いた。糖鎖アミノ 酸 31 の導入も，DIPCDI 打よび HOBt 条件で行った。糖鎖が ペプチドに導入されたあとは，縮合する反応溶液中の各アミ ノ酸の濃度を， $40 \mathrm{mM}$ になるよう維持し，糖水酸基へのアミ ノ酸のエステル化を抑え合成した $(32)$ 。全てのアミノ酸の導 入が終了後, $95 \% \mathrm{TFA}$ を用いて糖ペプチドを固相から切り出 した。そして，200 mM NaOH もしくは $20 \mathrm{mM} \mathrm{NaOH}$ を用い た短時間でのシアル酸の脱エステル化を行った。HPLC, 質 量分析による解析の結果，少量ながらセリンの側鎖から糖鎖 が脱離した生成物を確認したが，目的とするシアリル糖ペプ チドは効率よく得られていた。最後に逆相 HPLCで目的物を 生成し, シアリル- $\mathrm{T}_{\mathrm{N}}-\mathrm{MUC} 4$ ペプチド 32 を収率 $61 \%$ で得た。 
$\mathrm{mM} \mathrm{NaOH}$ solution for $10 \mathrm{~min}$ at $0^{\circ} \mathrm{C}$ or $20 \mathrm{mM} \mathrm{NaOH}$ solution for $1.5 \mathrm{~h}$. Extensive analysis of this reaction with HPLC and mass spectromertry, a tiny amount (5-7\% yield) of eliminated product was observed, but this reaction afforded sialyl- $\mathrm{T}_{\mathrm{N}}$-glycopeptide in good yield. Finally, purification of the crude material by a reverse-phase HPLC column afforded pure sialyl- $\mathrm{T}_{\mathrm{N}}-\mathrm{MUC} 4$ peptide 32 (61\% isolated yield). As shown here, we have found an interesting sialylation and efficient synthetic conditions for $O$-linked sialyl glycopeptides.

\section{New concept for native chemical ligation}

As mentioned in the introduction, the chemical synthesis of homogeneous glycoproteins is one of the currently available powerful approaches. In terms of this glycoprotein synthesis, native chemical ligation (NCL) is an efficient method in order to link peptide-segments through native amide bond (7). However, all target proteins don't have a cysteine residue at the suitable position for glycoeptide or glycoprotein syntheses. Because of this problem, convenient ligation methods instead of NCL reaction have been anticipated. In order to solve this problem, a reduction method changing from the sulfuhydryl group of cysteine to the hydrogen atom after NCL and utilizing an auxiliary group have been developed (34). In particular, a reduction method has been used in order to convert cysteine into alanine, which is frequently found in almost all protein sequences. We have also explored suitable NCL approaches to the synthesis of glycoproteins, and we found a new ligation position at the serine site in the consensus sequence (asparagine- $\mathrm{X}$-serine or -threonine: $\mathrm{X}$ is any amino acid except proline), where an asparagine residue is generally incorporated in $N$-linked oligosaccharide. Our concept is to convert the cysteine residue to a serine residue after conventional NCL, and this means that we can use NCL at the serine site in the protein sequence and at the consensus sequence. The synthetic strategy is shown in Fig. 4. The strategy employs three steps of conversion after NCL (Fig. 4 (a)); the $S$ methylation of cysteine by methyl 4-nitrobenzene sulfonate (Fig. 4 (b)) and intramolecular rearrangement by $\mathrm{CNBr}$ activation (Fig. 4 (c)) (34) followed by an $\mathrm{O}$ to $N$ acyl shift (Fig. 4 (d)). Activation by $\mathrm{CNBr}$ toward the $S$ methyl group resulted in intramolecular rearrangement by the action of the neighboring carbonyl oxygen and generates an $O$-ester peptide intermediate. This intermediate can be converted into the desired peptide through $\mathrm{O}$ to $\mathrm{N}$ acyl shift under a slightly basic condition (pH 7-8).

In order to confirm proof of concept, we first investigated the reaction process and yield by the use of model tetrapeptides having a cysteine residue corresponding to
ここに示したように，アミド化されたシアル酸を用いる興味 深いシアリル化反応を見出すとともに，O 型シアリルペプチ ドの効率的な合成を抽なうことができた。

D. 新しい native chemical ligation 法

冒頭でも述べたように, 単一構造の糖タンパク質の化学 的合成は有用な方法の 1 つである。この糖タンパク質の合成 については, native chemical ligation (NCL) が天然型のアミド 結合でペプチドセグメントを連結できるので有用である(7)。 しかし, 全ての標的タンパク質がシステイン残基を糖ペプチ ド合成のための適切な位置にもっているわけではないので, NCL が常に使えるわけではない。この問題のために, NCL に代わるペプチド連結法の開発が期待されている。この問題 を解決するために，NCL 後システインのスルフヒドリル基を 還元する方法や補助基を使った NCL 法が展開されている (33)。特に, 還元法は, システイン残基をタンパク質中しば しば見出されるアラニン残基に変換することができる。我々 も，適切な新しい NCL 法の開発を検討し， N 型糖鎖が付加す るコンセンサス配列のセリン残基が新しい NCL の場所に利用 できることを見出した。我々のコンセプトは，NCL 後，シス テイン残基をセリン残基に変換するもので，これは，コンセ ンサス配列のセリン部位が常に NCL に利用できることを意味 する。合成計画を図 4 に示した。この方法では, NCL（図 4 (a)）後 3 工程を経てセリンへと変換する。図 4 では, システ インを $\mathrm{S}$ メチル化 (b)し, CNBr 処理 (c)により隣接するカル ボニル基の反応を介する分子内転移により（34），O-エステル 誘導体を与える。そして，この中間体を弱塩基（pH 7-8）で 処理すると $\mathrm{O}-\mathrm{N}$ 転移によりセリン残基へと変換される。

このコンセプトを証明するために，我々は，まず，シス テイン残基をもつモデルのテトラペプチドを用いて, 反応機 構，収率などを確認する実験をおこなった（表 4)。 

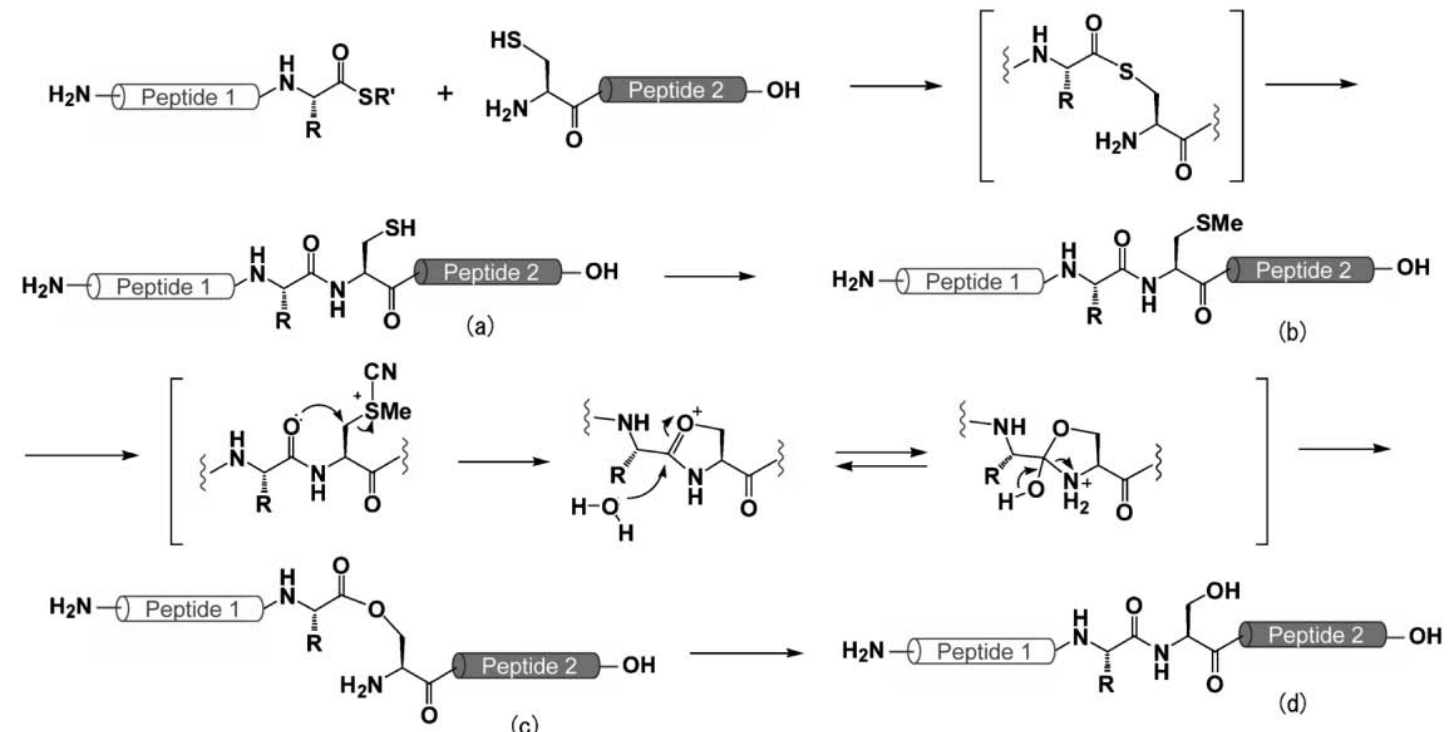

Fig. 4. Reaction mechanism of the conversion of cysteine to serine

Table 4. Conversion of cysteine to serine using model peptides

\begin{tabular}{clccc}
\hline Entry & $\begin{array}{l}\text { Cys peptide } \\
\rightarrow \text { Ser peptide }\end{array}$ & Cys-methylation & $\begin{array}{c}\text { CNBr } \\
\text { conversion }\end{array}$ & $\begin{array}{l}\text { O to N } \\
\text { acyl shift }\end{array}$ \\
\hline 1 & $\begin{array}{l}\text { Ac-ACGL (33) } \\
\rightarrow \text { Ac-ASGL (34) }\end{array}$ & quant. (>90\%) & $75 \%(62 \%)$ & quant. (70\%) \\
2 & $\begin{array}{l}\text { VDKAVCGL (35) } \\
\rightarrow \text { VDKAVSGL (36) }\end{array}$ & $97 \%(90 \%)$ & $85 \%(63 \%)$ & $90 \%(82 \%)$ \\
3 & $\begin{array}{l}\text { LFRVYCNFLRG (37) } \\
\rightarrow \text { LFRVYSNFLRG (38) } \\
4 c-G C G M(O) A(39)\end{array}$ & $90 \%(81 \%)$ & $51 \%(41 \%)$ & quant. (77\%) \\
& $\rightarrow A c$-GSGMA (40) & quant. (80\%) & $82 \%(73 \%)^{* *}$
\end{tabular}

Yields show conversion yields as estimated by HPLC area intensity, with an isolated yield indicated in the parenthesis (*: one-pot reaction).

the product after NCL (Table 4).

As shown in Table 4, all peptides could be converted to products after the conversion of the cysteine residue to a serine residue. In addition, we confirmed whether Lamino acids in the product cause epimerization or not by comparison with authentic peptides. In the case of tetrapeptide ( $A c$-ACGL-OH: entry 1$)$, we compared this peptide with authentic peptide containing D-amino acids such as $A c-{ }^{\mathrm{D}} \mathrm{ASGL}-\mathrm{OH}, A c-\mathrm{A}^{\mathrm{D}} \mathrm{SGL}-\mathrm{OH}, A c-{ }^{\mathrm{D}} \mathrm{A}^{\mathrm{D}} \mathrm{SGL}-$ $\mathrm{OH}$ and $A c$-ASGL-OH, by HPLC and NMR analysis. These results proved that the product $\mathbf{3 4}$ was identical to $A c$-ASGL-OH and the conversion method did not cause any epimerization in the peptide. The experiments using
表 4 に示したように, 全てのペプチドの例に抢いて, シ ステイン残基からセリン残基に変換することができた。ま た, 我々は, この際, L-アミノ酸がエピメリゼーションを起 こしていないか標準サンプルを別途合成し，そして比較し確 認した。テトラペプチド $(A c-\mathrm{ACGL}-\mathrm{OH})$ の場合，D-アミ ノ酸を含む, $A c-c^{\mathrm{D} A S G L-O H}, A c-\mathrm{A}^{\mathrm{D} S G L}-\mathrm{OH}, A c-{ }^{\mathrm{D}} \mathrm{A}^{\mathrm{D} S G L}-$ $\mathrm{OH}, A c-\mathrm{ASGL}-\mathrm{OH}$ を合成し HPLC および NMR で比較し た。その結果, 生成物 2 のテトラペプチドは, 標準サンプル の $A c-\mathrm{ASGL}-\mathrm{OH}$ に完全に一致し, 反応過程でエピメリゼー ションを起こしていないことが確認できた。また，オクタ， ウンデカペプチドでも効率よくこの変換反応をすることに成 


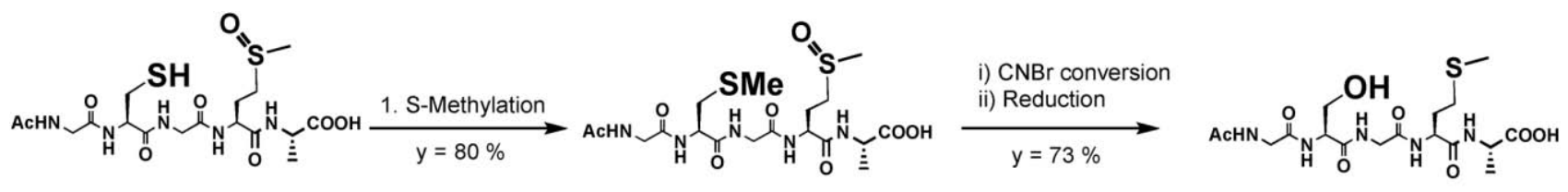

39

41

40

Scheme 4. Conversion of cysteine to serine in a pentapeptide containing a methionine residue. Yields show the isolated yield. S-methylation was performed on 39, which was synthesized by SPPS.

octa and undecapeptides (Table 4, No 2 and 3) also exhibited moderate yield.

One problem in using $\mathrm{CNBr}$ was the oxidation of methionine during this process. The reaction using $\mathrm{CNBr}$ also cleaves the methionine site. In order to avoid cleavage of the methionine site, we introduced methionine in the sulfoxide form. Because the sulfoxide form of methionine cannot be activated by $\mathrm{CNBr}$ reaction (34), we expected an oxidation/reduction protocol (36) would allow the use of this new approach for the synthesis of other peptides having methionine residues. We examined this strategy toward pentapeptide 39 having cysteine and sulfoxide of methionine. This model peptide was synthesized by the use of the sulfoxide of the methionine derivative during simple SPPS. After $S$-methylation, conversion of $S$-methyl cysteine to a serine residue and the subsequent reduction of sulfoxide by $\mathrm{NH}_{4} \mathrm{I}, \mathrm{SMe}_{2}$ and TFA (36) was performed as a one-pot reaction. This protocol afforded the desired pentapeptide 40 in good yield (73\% isolated yield, scheme 4).

Because we confirmed that this new method could be used for the conversion of a cysteine residue to a serine residue, we examined the synthesis of glycopeptides having complex type oligosaccharides by use of the new method. We selected a fragment of erythropoietin (79 to 98 residues; Scheme 5) as a model glycopeptide. We prepared substrate glycosyl hexapeptide thioester $\mathbf{4 2}$ having complex type $N$-linked asialooligosaccharides, and tetradecapeptide $\mathbf{4 3}$ having a cysteine residue, by a reported method (37).

The NCL reaction between the glycopeptide thioester $\mathbf{4 2}$ and tetradecapeptide $\mathbf{4 3}$ afforded the desired glycosyl icosapeptide 44. Toward this glycopeptides having free sugar hydroxyl groups, we examined $S$-selective methylation (Fig. 5 (a)-(c)), followed by activation of the $S$-methyl cysteine residue by $\mathrm{CNBr}$ (Fig. 5 (d)-(g)). However, this product was observed in the form of broad peaks by RP-HPLC (Fig. 5 (e)). Because oligosaccharides on the peptide have many free hydroxyl groups, we concluded that this was random formylation of the sugar
功した。

問題としては，CNBr 処理をする際に起こる，メチオ二 ン残基の酸化反応である。CNBr 反応は，メチオニン残基の 部位でペプチド鎖を切断する反応を起こす。この切断反応を 避けるために, 我々は, スルホキシド型のメチオニンを利用 することにした。このようにして抢けば，CNBrでは反応を 起こさないので(35), 最後に, 還元して通常のメチオニン残 基に戻すことができる(36)。我々は，このスルホキシド型の メチオニン, システイン残基を有するペンタペプチド 39 を固 相合成により調製し，その確認実験を行った。ペンタペプチ ド39のスルフヒドリル基をメチル化後, セリン残基へ変換し た。そして TFA 存在下, $\mathrm{NH}_{4} \mathrm{I}, \mathrm{SMe}_{2}(36)$ でワンポットで還元 したところ，効率よく目的物であるペンタペプチド 40 がよい 収率で得られた（yield $=73 \%$ 単離收率， scheme 4$)$ 。

以上のことから，新しいコンセプトが利用できることが 確認できたので，複合型糖鎖をもつ糖ペプチドの合成を検討 することにした(scheme 5)。モデルペプチドとして，エリス ロポエチンの 79-98 残基を選び検討した。複合型アシアロ糖 鎖をもつペプチドチオエステル $\mathbf{4 2}$ とテトラデカペプチド $\mathbf{4 3}$ は，既に報告した方法で合成した(37)。そして，これらの NCL 反応を抢なったところ, 糖鎖化, イコサペプチド 44 を与えた。そして，遊離の糖水酸基をもつこの糖ぺプチドに 対して, S-メチル化(図 5(a)-(c)), CNBr 処理 (図 5(d)-(g)) を行った。しかし, この $\mathrm{CNBr}$ 処理に抢いては, 生成物が幅 広い HPLC ピークを示した (図 $5(\mathrm{e}))$ 。これは，糖水酸基が遊 離であるため, 蟻酸と $\mathrm{CNBr}$ 条件下で，それら水酸基に対す る非特異的なホルミルエステル化が起こったからであると考 えている。そこで, 凍結乾燥後, $5 \%$ ヒドラジン水溶液あるい は, $\mathrm{pH} 10$ 程度の塩基性水溶液で 10 分間処理し, O-N 転移々 脱ホルミルエステル化を抢こなった。図 5 (f) に示したよう に，目的とするセリンを持った糖ぺプチド 46 を得ることがで きた。得られた糖ペプチドの構造と純度は, 別途固相合成に 


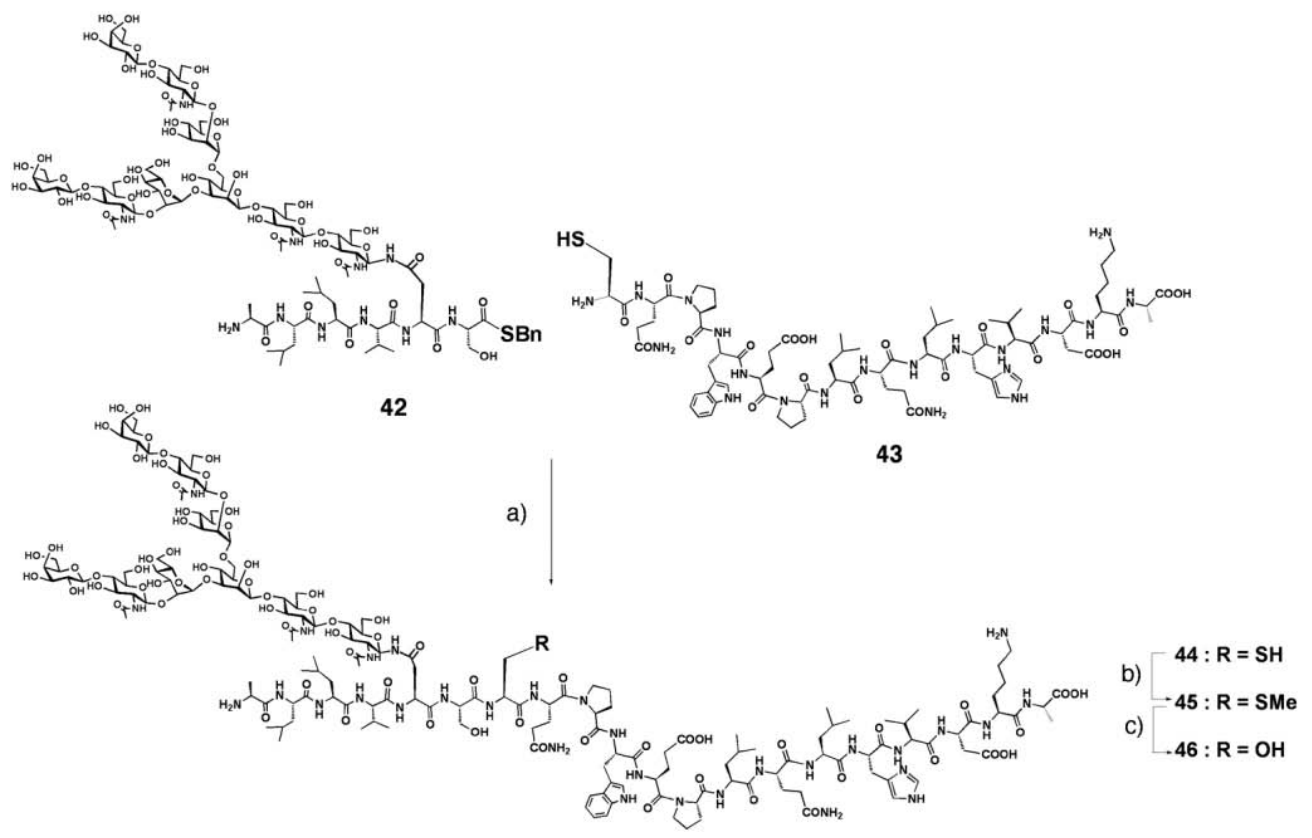

Scheme 5. Synthesis of $N$-linked glycosyl icosapeptide through the new ligation method at the serine site. a) $6 \mathrm{M}$ Guanidine hydrochloride, $0.1 \mathrm{M}$ sodium phosphate buffer at $\mathrm{pH} 7.1$ containing thiophenol $(0.5 \% \mathrm{v} / \mathrm{v})$, benzylmercaptane $(0.5 \% \mathrm{v} / \mathrm{v}), 70 \%$ isolated yield; b) $6 \mathrm{M}$ Guanidine hydrochloride, $0.25 \mathrm{M}$ Tris $\cdot \mathrm{HCl}, 3.3 \mathrm{mM}$ EDTA $\cdot 2 \mathrm{Na}$ buffer at $\mathrm{pH}$ 8.6, $\mathrm{CH}_{3} \mathrm{CN}$, methyl 4-nitrobenzenesulfonate, $85 \%$ conversion yield estimated by HPLC area intensity (67\% isolated yield); c) i) $\mathrm{CNBr}, 80 \% \mathrm{HCOOH}$ ii) $5 \%$ hydrazine hydrate solution, $80 \%$ conversion yield estimated by HPLC area intensity ( $70 \%$ isolated yield).

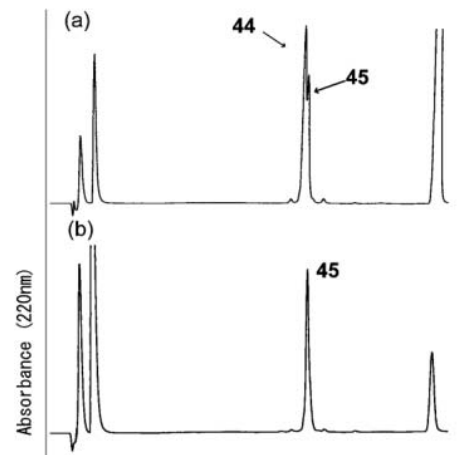

(c)

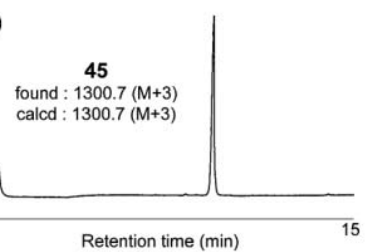

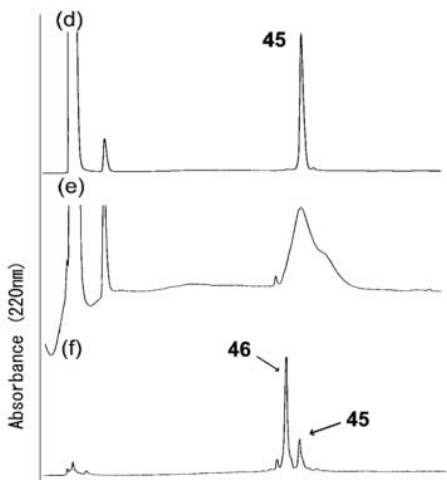

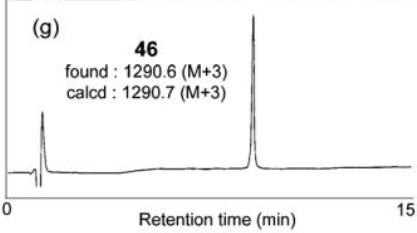

Fig. 5. HPLC profiles for the conversion of cysteine to serine residue in the $\boldsymbol{N}$ linked glycosyl icosapeptide 46. $S$-Methylation reaction: (a) $\operatorname{start~}(1 \mathrm{~min}>\mathrm{t}$ ); (b) $20 \mathrm{~min}$; and (c) after purification. Conversion reaction of $S$-methyl cysteine to a serine residue: (d) start $(1 \mathrm{~min}>\mathrm{t})$; (e) $38 \mathrm{~h}$; (f) after hydrazine treatment; and (g) after purification. Elution Condition; Imtakt column C- $18,3 \mu \mathrm{m}, 75 \mathrm{~mm} \times 4.6 \mathrm{~mm}$ linear gradient of $18 \rightarrow 45 \%$ containing $0.09 \%$ TFA in $0.1 \%$ TFA aqueous over $15 \mathrm{~min}$ at a flow rate of $1.0 \mathrm{ml} / \mathrm{min}$. 


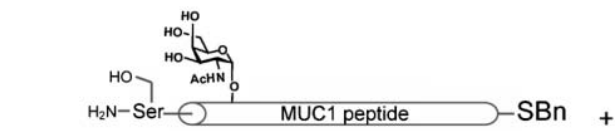

47

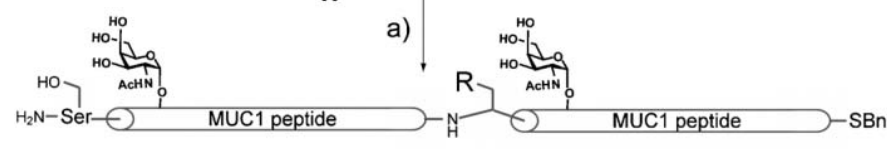

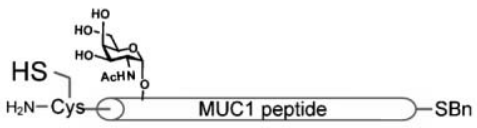

48

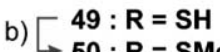

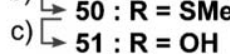

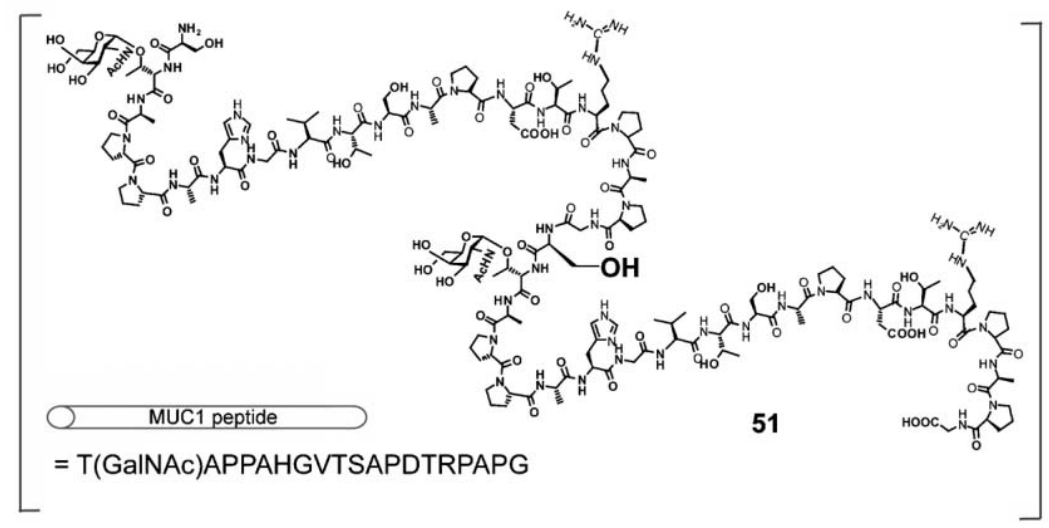

Fig. 6. Conversion of cysteine to serine for the synthesis of MUC1 repeat segment. a) $6 \mathrm{M}$ Guanidine hydrochloride, $0.1 \mathrm{M}$ sodium phosphate, $60 \mathrm{mM}$ 4-mercaptophenyl acetic acid, $20 \mathrm{mM}$ tris(2-carboxylethyl)phosphine buffer at $\mathrm{pH}$ 7.2; b) Methyl 4-nitrobenzenesulfsonate, $6 \mathrm{M}$ Guanidine hydrochloride, $0.25 \mathrm{M}$ Tris $\cdot \mathrm{HCl} 3.3 \mathrm{mM}$ EDTA $\cdot 2 \mathrm{Na}$ buffer at $\mathrm{pH}$ $8.6, \mathrm{CH}_{3} \mathrm{CN}$, c) i) $\mathrm{CNBr}, 80 \% \mathrm{HCOOH}$ ii) TFA, $\mathrm{NH}_{4} \mathrm{I}, \mathrm{Me}_{2} \mathrm{~S}$ iii) $5 \%$ hydrazine hydrate solution.

hydroxyl groups under the formic acid and $\mathrm{CNBr}$ conditions. After lyophilization, the residue was dissolved in $5 \%$ hydrazine hydrate solution (or a slightly basic solution: $<\mathrm{pH} \mathrm{10)}$ for $10 \mathrm{~min}$ (Fig. 5 (f)) in order for this peptide to afford the $O$ to $N$ shift and to remove the formyl group from the sugar hydroxyl groups. As shown in Fig. 5 (f), this treatment successfully afforded the target glycosyl icosapeptide $\mathbf{4 6}$ having the serine residue. The structure and purity of this glycopeptide was confirmed by comparison with the authentic sample synthesized by solid phase peptide synthesis.

In addition, we also examined the synthesis of $O$ linked glycopeptide, the MUC1 repeat segment with the variable number tandem repeat region (38) by use of the new ligation concept. This MUC1 segment has proline, threonine and serine residues. After preparation of two $O$ linked glycosyl icosapeptides having mono $\mathrm{N}$-acetyl galactosamine segments, we examined the new ligation strategy and this reaction afforded the desired glycosyl tetracontapeptide 49 having the cysteine residue (Fig. 6).

Then cysteine residue at the ligation position in glycopeptide 49 was converted into a serine residue through the same NCL approach. This conversion afforded the desired glycopeptide $\mathbf{5 1}$ in moderate yield (overall
より調製しておいた標準サンプルと比較し，この反応が目的 どおりに進行したことを確認した。

更に，我々は，MUC1 の繰り返し構造をもつ O 型糖鎖ぺ プチドの合成にも，この新しい NCL 法を応用した。この MUC1 は, プロリン, トレオニン, セリンを豊富にもつペプ チドである(38)。図 6 に示したように，N-アセチルガラクト サミンをもつ 2 つの $\mathrm{O}$ 型糖ペプチドを合成後, 新しい NCL 法を適応して連結を試みた。この NCLでは，連結された糖ぺ プチド 49 が効率よく得ることができ, 続くセリンへの変換反 応により，目的とする糖ぺプチド $\mathbf{5 1}$ が良好な収率で得られた (HPLC に上る全変換収率 43\%，16\% の単離収率)。得られた 生成物の構造は，アクチナーゼ $\mathrm{E}$ というペプチダーゼを用い て連結部位を含む小型ペプチド（SAPDTRPAPGST (GalNAc) APPAHG）に変換後, 別途合成した同じ構造の標準糖ペプチ 
$43 \%$ conversion yield estimated by HPLC area intensity, $16 \%$ isolated yield,).

In order to confirm the structure of the final glycopeptide, we examined peptide digestion of compound 51 by Actinase E (Streptomyces griseus, Kaken pharma, Tokyo) and this non-specific digestion afforded a glycosyl octadecapeptide with a ligation site (SAPDTRPAPGST (GalNAc)APPAHG). We compared this peptide fragment and with the authentic glycosyl octadecapeptide synthesized by SPPS and we confirmed that both glycosyl octadecapeptide fragments were identical. As shown here, a new ligation method has been found which can be used for the synthesis of both $O$-linked and $N$-linked glycopeptides.

\section{E. Conclusion}

We have found an interesting sialylation reaction using Neu5Ac-1-amide derivatives, and these reactions exhibited good $\alpha$-selectivity and yield. Simple modification by an amide group at the $C(1)$ position of sialic acid instead of the ester group forms an interesting intermediate to afford $\alpha$-selectivity. This method was also developed for the synthesis of glycopeptides having a sialyl- $\mathrm{T}_{\mathrm{N}}$ epitope and its $O$-linked type sialylglycopeptide, the MUC4 fragment having sialyl- $\mathrm{T}_{\mathrm{N}}$. In order to couple these $O$-linked glycopeptide and $N$-linked glycopeptides, we also identified a new ligation strategy using a conversion strategy of a cysteine to serine residue. This method was successfully used for the synthesis of both $N$-linked and $O$-linked glycopeptides. Research is currently in progress to utilize this approach for the synthesis of a number of $O$-linked and $N$-linked glycoproteins.
ドと比較して，双方が一致することを確認し，本手法が正し く利用できることを確認した。以上示したように, 我々は, 新しい NCL コンセプトを見出し， N 型抢よび $\mathrm{O}$ 型糖ペプチ ドの合成に利用できることを示した。

\section{E. おわりに}

我々は，アミド化された新しいシアル酸供与体を用いる $\alpha$ 選択的な興味深いシアリル化反応を見出した。これは, シ アル酸の 1 位に簡単な化学修飾をすることで $\alpha$ 選択性を与え る興味深い反応中間体を与えたようである。この方法を用い ることで Sialyl- $\mathrm{T}_{\mathrm{N}}$ 抗原をもつ O 型糖ペプチドである MUC4 フラグメントの合成に展開することができた。そして， O 型, $\mathrm{N}$ 型糖ペプチドを連結していくために，我々は，システイン 残基をセリン残基に変換する手法を組み込んだ新しい NCL の 方法を見いだし，効率よくそれら糖ペプチドを与えることを 確認した。研究はさらに発展途上にあり, 今後 $\mathrm{O}$ 型および $\mathrm{N}$ 型糖鎖をもつタンパク質の合成を展開していく予定である。

\section{References}

1. Wong, C. H. (2005) J. Org. Chem. 70, 4219-4225

2. Varki, A., Cummings, R., Esko, J., Freeze, H., Hart, G., and Marth, J. (1999) Essentials of Glycobiology, Cold Spring Harbor, New York

3. Marcaurelle, L. A., Mizoue, L. S., Wilken, J., Oldham, L., Kent, S. B. H., Handel, T. M., and Bertozzi, C. R. (2001) Chem. Eur. J. 7, 1129-1132

4. Hojo, H., Matsumoto, Y., Nakahara, Y., Ito, E., Suzuki, Y., Suzuki, M., Suzuki, A., and Nakahara, Y. (2005) J. Am. Chem. Soc. 127, 13720-13725

5. Yamamoto, N., Tanabe, Y., Okamoto, R., Dawson, P. E., and Kajihara, Y. (2008) J. Am. Chem. Soc. 130, 501-510

6. Aimoto, S. (2001) Curr. Org. Chem. 5, 45-87

7. Dawson, P. E., Muir, T. W., Lewis, I. C., and Kent, S. B. H. (1994) Science 266, 776-779

8. Danishefsky, S. J., and Allen, J. R. (2000) Angew. Chem. Int. Ed. 39, 836-863

9. Okamoto, R., Souma, S., and Kajihara, Y. (2008) J. Org. Chem. 73, 3460-3466

10. Okamoto, R., and Kajihara, Y. (2008) Angew. Chem. Int. Ed. 4, 5402-5406

11. Boons, G. J., and Demchenko, A.V. (2000) Chem. Rev. 100, 4539-4565

12. Cai, S., and Yu, B. (2003) Org. Lett. 5, 3827-3830

13. DeMeo, C., and Parker, O. (2005) Tetrahedron Asymmmetry 16, 303-307

14. Ishiwata, A., and Ito, Y. (2003) Synlett. 9, 1339-1343

15. Lin, C. C., Huang, K. T., and Lin, C. C. (2005) Org. Lett. 7, 4169-4172

16. Tanaka, H., Adachi, M., and Takahashi, T. (2005) Chem. Eur. J. 11, 849-862

17. Ando, H., Koike, Y., Ishida, H., and Kiso, M. (2003) Tetrahdron Lett. 44, 6883-6886

18. Ando, H., Koike, Y., Koizumi, S., Ishida, H., and Kiso, M. (2005) Angew. Chem. Int. Ed. 44, 6759-6763

19. Tanaka, K., Goi, T., and Fukase, K. (2005) Synlett. 19, 2958-2962 
20. Tanaka, H., Nishiura, Y., and Takahashi, T. (2006) J. Am. Chem. Soc. 128, 7124-7125

21. Farris, M., and DeMeo, C. (2007) Tetrahedron Lett. 48, 1255-1227

22. Crich, D., and Li, W. (2007) J. Org. Chem. 72, 2387-2391

23. a) Danishefsky, S. J., DeNinno, M. P., and Cheng, S. H. (1988) J. Am. Chem. Soc. 110, 3929-3940; b) Ye, X. S., Huang, X., and Wong, C. H. (2001) Chem. Commun. 974-975

24. Kuhn, R., Lutz P., and Macdonald, D. (1966) Chem. Ber. 99, 611

25. Myers, R. W., Lee, Y. C., Thomas, G. H., Reynolds, L. W., and Uchida, Y. (1980) Anal. Biochem. 101, 166-174

26. Roy, R., and Pon, R. A. (1990) Glycoconjugate J. 7, 3-12

27. Dziadek, S., Brocke, C., and Kunz, H. (2004) Chem. Eur. J. 10, 4150-4162

28. Dekker, J., Rossen, J. W. A., Buller, H. A., and Einerhand, A. W. C. (2002) Trends. Biochem. Sci. 27, 126-131

29. Singh, A. P., Chaturvedi, P., and Batra, S. K. (2007) Cancer Res. 67, 433-436

30. Nakahara, Y. (2007) Biopolymers 88, 308-324

31. Chen, X. T., Sames, D., and Danishefsky, S. J. (1998) J. Am. Chem. Soc. 120, 7760-7769

32. Yamamoto, N., Takayanagi, A., Yoshino, A., Sakakibara, T., and Kajihara, Y. (2007) Chem. Eur. J. 13, 613-625

33. Christian, H., and Oliver, S. (2008) Angew. Chem. Int. Ed. 47, 1553-1556

34. Gross, E., and Morell, J. L. (1974) Biochem. Biophys. Res. Commun. 59, 1145-1150

35. Kaiser, R., and Metzka, L. (1999) Anal. Biochem. 266, 1-8

36. Hackenberger, C. P. R. (2006) Org. Biomol. Chem. 4, 2291-2295

37. Kajihara, Y., Yoshihara, A., Hirano, K., and Yamamoto, N. (2006) Carbohydr. Res. 341, 1333-1340

38. Hanisch, F. G., and Muller, S. (2000) Glycobiology 10, 439-440

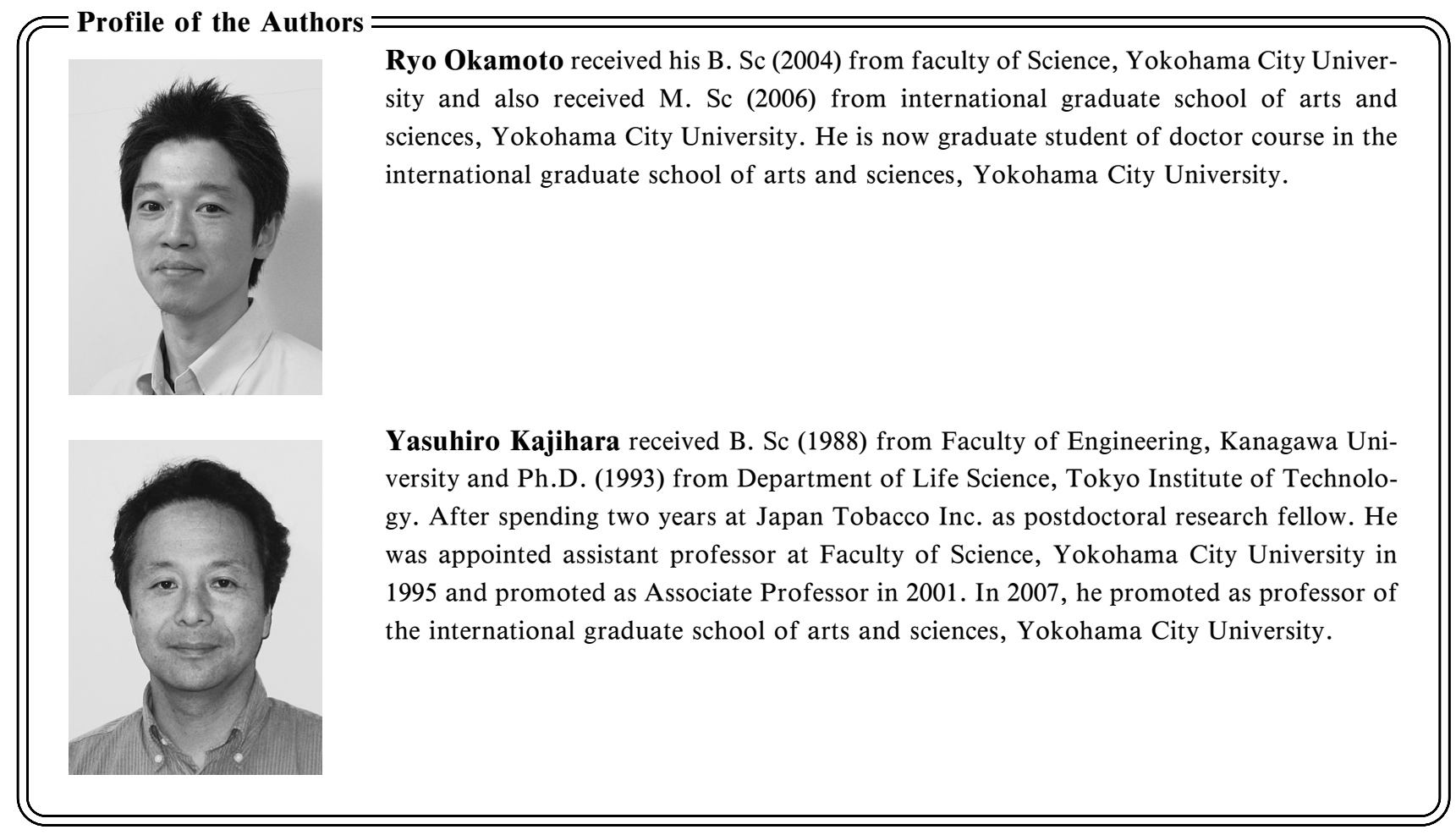

